VOX PATRUM 37 (2017) t. 68

Alexandru PRELIPCEAN ${ }^{*}$

\title{
DOES THE GREAT CANON OF ANDREW OF CRETE SPEAK ABOUT THE HERESIES AND THEIR COMBATING? Brief Remarks
}

If the literature dedicated to Saint Andrew of Crete (ca. 660-740) was concerned at the beginning of the twentieth century with the investigation of the biographical aspect of the Byzantine Hymnographer ${ }^{1}$, the literature of the last decades has been concerned with the recovery of various hymnographic ${ }^{2}$ and homiletic $^{3}$ productions, alongside with analysis from theological (-spiritual)

\footnotetext{
* Alexandru Prelipcean, Asist. PhD. Cand. - Faculty of Orthodox Theology "Dumitru Stăniloae" from Iaşi; email: alprelipcean@yahoo.com.

${ }^{1}$ See the Vita of Andrew written by the Patrikios and Quaestor Niketas and published in 1898 by

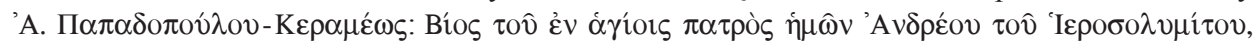

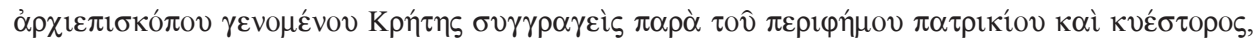

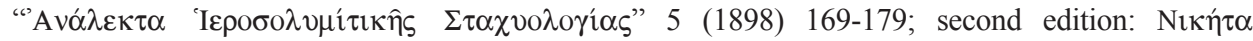

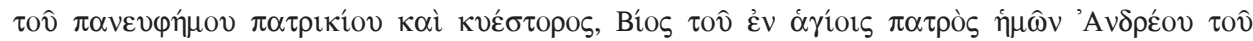

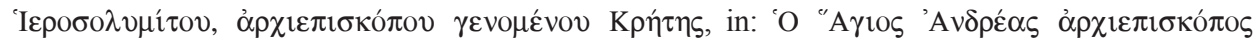

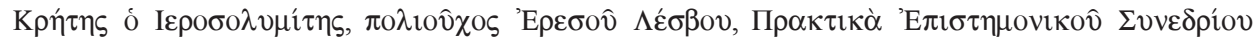

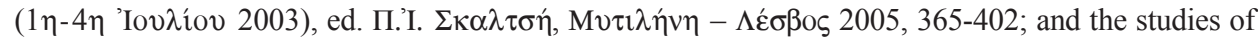
S. Vailhé, Saint André de Crète, EO 5 (1901-1902) 378-387; C. Émereau, Hymnographi Byzantini quorum nomina in litteras digessit notulisque adornavit, EO 21 (1922) 127-128 and 258-279 (Andreas Cretensis, ibidem, p. 267-271); A. Vinogradov, Viața Sfântului Andrei Criteanul, Arhiepiscopul şi Mitropolit al Cretei (Schiță aghiografică), "Luminătorul” 72 (1932) 114-120 (part 1), 147-153 (part 2).

${ }^{2}$ See, as example: G. Schiró, Caracteristiche dei canoni di Andrea Cretese. Studio su alcune com-

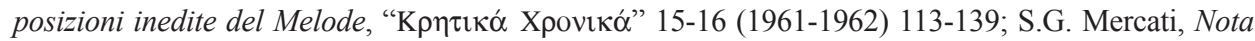
a due passi del canone di Sant'Andrea per San Giorgio, "Byzantion” 32 (1962) 311-312; M.A. Magri, L'inedito Canon de Requie di Andrea Cretese, "Helikon" 9-10 (1969-1970) 475-513; E. Follieri, Un canone inedito di S. Andrea di Creta per l'Annunciazione (Vat. gr. 2000 e Crypt. 4. $\alpha$. VII), in: Collectanea Vaticana in honorem Anselmi M. Card. Albareda, Studi e Testi 219, Città del Vaticano 1962, 337-

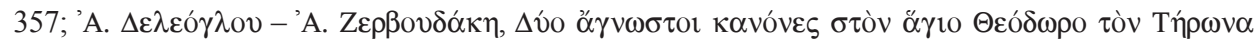

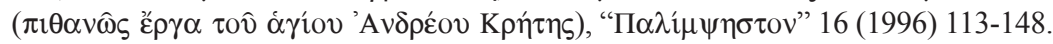

${ }^{3}$ See, as exemple: M.B. Cunnigham, Andreas of Crete's Homilies on Lazarus and Palm Sunday: a Critical Edition and Commentary, Birmingham 1983; idem, Andreas of Crete's homilies on Lazarus and Palm Sunday: the Preacher and his Audience, StPatr 31 (1997) 22-41; idem, Andrew of Crete: A High-Style Preacher of the Eighth Century, in: Preacher and His Audience: Studies in Early Christian and Byzantine Homiletics, ed. M.B. Cunnigham - P. Allen, Leiden - Boston - Köln 1998, 267-293; Andrew of Crete's Homilia de exaltatione s. crucis (CPG 8199; BHG 434f.). Editio

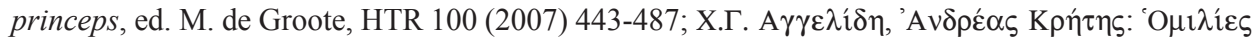


point of view of the Great Canon ${ }^{4}$. However, studies that reflect the situation of the polemical intentions of the Great Canon, fundamental work of the Cretan author ${ }^{5}$, still remained unwritten. Where should such a study start from? We believe that from the Bíos itself of the Cretan author, given by the fact that in 712, under the usurper Emperor Philippicus Bardanes (711-713), Andrew of Crete will sign the acts of the Monothelitism Council. The Chronographia of Theophanes the Confessor is the only official source which is reminiscent of the signature of the official act by Andrew ${ }^{6}$; the remaining of the official sources in relation with the life of Cretan author's passing off this event in the shadow ${ }^{7}$. The following interrogation is brought fourth: is it possible that the Great Canon reflects those polemical intentions of Andrew's period and strikes on various heresies, even on Monothelitism, which has been approved by the Byzantine Hymnographer himself for a very short period? Is it possible

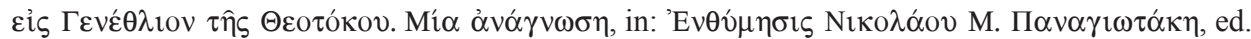

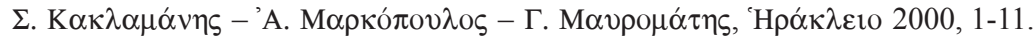

${ }^{4}$ See, as example: O. Clément, Le chant des larmes. Essai sur le repéntir. Suivi de la traduction

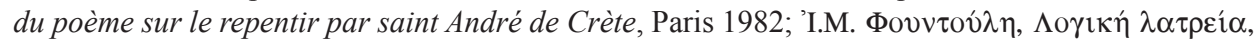

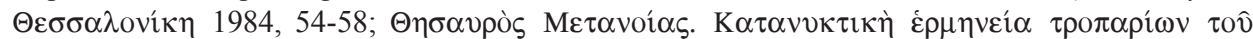

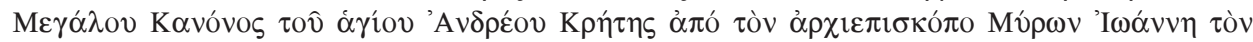

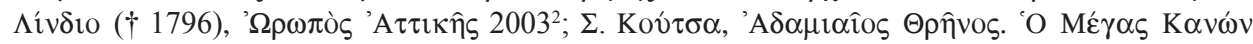

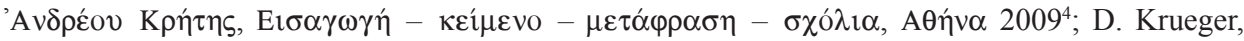
The Great Kanon of Andrew of Crete, the Penitential Bible, and the Liturgical Formation of the Self in the Byzantine Dark Age, in: Between Personal and Institutional Religion. Self, Doctrine, and Practice in Late Antique Eastern Christianity, ed. B. Bitton-Ashkelony - L. Perrone, Turnhout 2013, 57-97; A. Prelipcean, From Adam to Moses: the Typology of the Old Testament characters from the Kontakia of Romanos the Melodist and its Assessment on the Great Canon of Andrew of Crete", "Review of Ecumenical Studies" 7 (2015) 388-421.

${ }^{5}$ For the text of the Great Canon, I used - in the absence of any critical editions - the official text included in PG 97, 1329D - 1386C.

${ }^{6}$ Cf. Theophanes, Chronographia, PG 108, 736C. 773B - 776A.

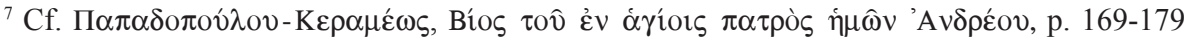

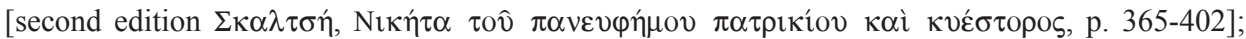

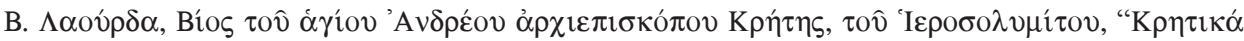

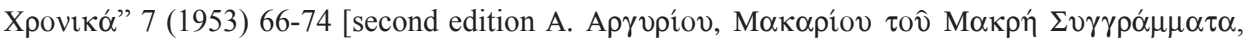

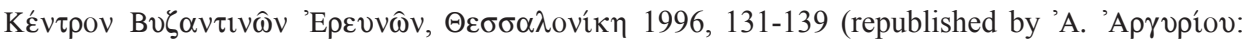

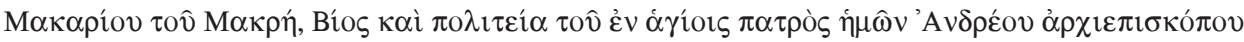

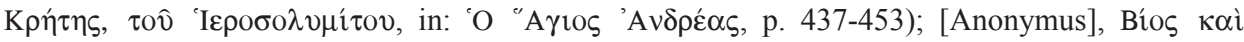

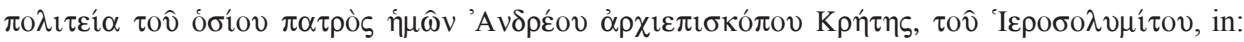
Menologii Anonymi Byzantini. Saeculi X Quae Supersunt, ed. V.V. Latyšev, Subsidia Byzantina

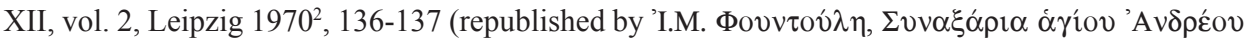

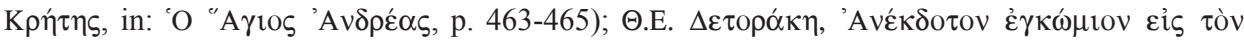

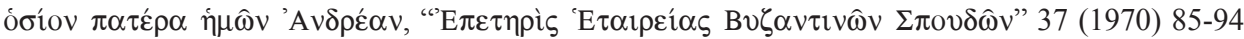

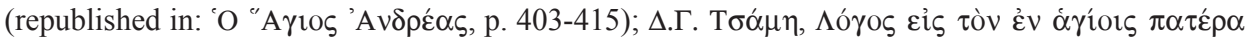

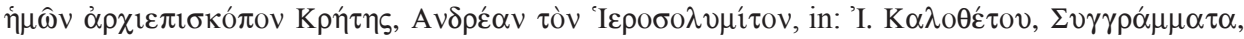

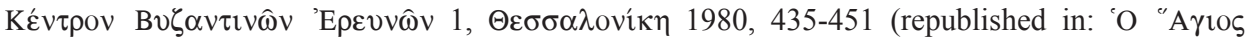

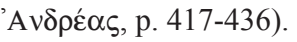


that Andrew of Crete be interested in his fundamental work to develop the Church's speech against heresies, which has been arisen over time inside of it, and present the Great Canon as a summary of the Church's fight against heresies and heresiarchs? There are some questions whose answer was not offered in the Byzantine literature dedicated to our Hymnographer. This very fact should not surprise us at all if we take into account the opinion of Father George Florovsky. According to his point of view, in the Great Canon the dogmatic themes are $\mathrm{few}^{8}$. The Florovsky's opinion could be supported today by other numerous ideas, which analyze the Great Canon (only) from a spiritual perspective ${ }^{9}$ rather than the dogmatic intentions from a Byzantine period, where the heresies were beginning slowly to turn off.

1. The heresies against to the Trinity doctrine. In all stanzas (troparia) dedicated to the Holy Trinity ( $\delta \circ \xi \alpha \sigma \tau \imath \kappa o ́ v$ ), the Byzantine Hymnographer develops the theological reality that God is Trinity of Persons, three consubstantial Persons: "I confess Thee as undivided in Essence, unconfused in Persons, One Triune Divinity"10, "I am the Trinity, simple and undivided, yet divided in Three Persons; and I am the Unity, united by Nature, says the Father and the Son and the Divine Spirit"11, "O Trinity, Who surpasses all creation and is adored in Unity"12. Although Saint Andrew mentions some Trinitarian aspect (the birth of the Son without beginning ${ }^{13}$ and the procession of the Spirit ${ }^{14}$ ), concrete and direct references to anti-Trinitarian heresies are quite missing.

However we can talk about some allusions with polemic intentions. First of those, identified and recorded for the first time by the Greek theologian Athanasios Glaros, in his doctoral thesis dedicated to the Divine Pedagogy in Great

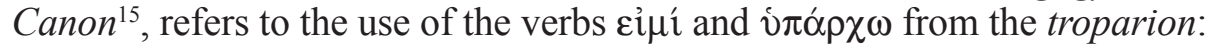

"I am the Trinity, simple and undivided, yet divided in Three Persons; and I am the Unity, united by Nature, says the Father and the Son and the Divine

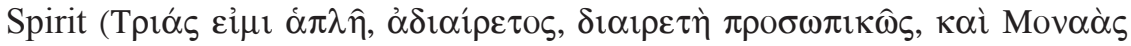

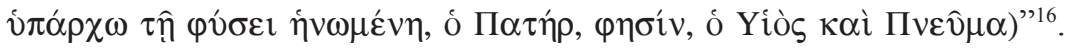

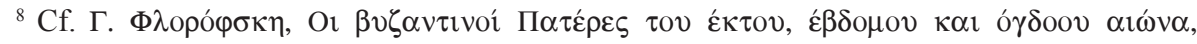

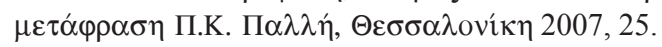

${ }^{9}$ See the footnote 4 .

${ }^{10}$ Andreas Cretensis, Magnus Canon, PG 97, 1353A. All English translation of the Great Canon of St. Andrew of Crete is taken from: https://www.antiochianladiocese.org/files/service_texts/ great_lent/great_compline/Repentance-Canon-MONDAY.pdf

${ }^{11}$ Ibidem, $\mathrm{PG}$ 97, 1380C.

${ }^{12}$ Ibidem, PG 97, 1336B.

${ }^{13} \mathrm{Cf}$. ibidem, PG 97, 1345B, 1377D.

${ }^{14} \mathrm{Cf}$. ibidem, PG 97, 1368B.

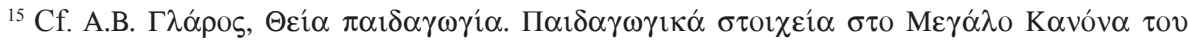

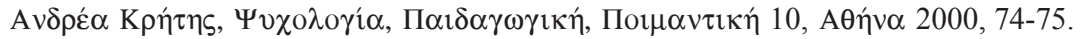

${ }^{16}$ Andreas Cretensis, Magnus Canon, PG 97, 1360D - 1361A. 


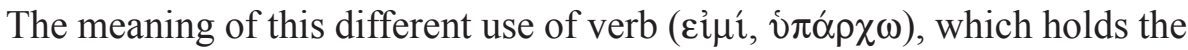
same hermeneutical value, it seems to be - in Glaros's opinion - the visible sign of an East climate, which, in the period of Byzantine poet, was opposing to the Western space which considered the nature (substantia) superior to the hypostases. The Byzantine melodist apparently tried to warm his audience by the danger of considering nature as the fourth Person of the Trinity ${ }^{17}$.

The second allusion with polemical purpose concerns the Pneumatological heresy. Throughout the Great Canon, the Byzantine author draws attention to the veneration of the Holy Spirit, saying that "I sing praises to the Holy Spirit Who shines forth with the Father and the Son"18. Obviously such an expression reflects the very teaching of the Church against to the Macedonian heresy, according to which the Holy Spirit was created by the Son of God and was thus subordinate to the Father and the Son. Of course, because of this reason the Holy Spirit does not get the same honor as the other two Persons of the Trinity. In another stanza Andrew does not forget to emphasize the doctrinal truth that the whole Church glorifies the Father, the Son and the Holy Spirit ${ }^{19}$. Other theological issues which concerned or made allusions to the anti-Trinitarian heresies are missing.

2. The Christological heresies and their combating. Even in the case of Christology we couldn't find, in the fundamental work of Andrew, clear indications regarding the various heresies. The Byzantine Hymnographer sketches the doctrinal truth that, in Christ, we find two natures united perfectly ${ }^{20}$, that He voluntarily assumed all human except the $\sin ^{21}$ and, through Him, the laws of nature are renewed ${ }^{22}$. Andrew does not mention the name of any heretic explicitly condemned by the Church, as Romanos the Melodist does, for example, in his remarkable kontakia ${ }^{23}$, as neither intends to draw the attention to the theological currents of his period. Obviously we have in our mind the Monothelitism doctrine, which returned to the forefront by the usurper Emperor Philippicus Bardanes, hence contemporary with Andrew. We might expect probably that after the retraction of the official act signed in 712, Andrew reflected at least in part, in the text of the Canon, at the Church's teaching regarding this doctrine. He was not doing it at all ${ }^{24}$, and the explanation could be given by the contents of the letter dedicated to Archdeacon Agathon (in

\footnotetext{
${ }^{17}$ Cf. $\Gamma \lambda \alpha ́ \rho \rho \varsigma, ~ \Theta \varepsilon i ́ \alpha ~ \pi \alpha i \delta \alpha \gamma \omega \gamma i \alpha$, p. 75.

${ }^{18}$ Andreas Cretensis, Magnus Canon, PG 97, 1368B.

${ }^{19} \mathrm{Cf}$. ibidem, PG 97, 1385C.

${ }^{20} \mathrm{Cf}$. ibidem, PG 97, 1381B.

${ }^{21}$ Cf. ibidem, PG 97, 1381A.

${ }^{22}$ Cf. ibidem, PG 97, 1353A.

${ }^{23}$ See, for example, the kontakion $8\left(1 \sigma \tau^{3}\right)$ of Romanos, where the Hymnographer calls Arians di-

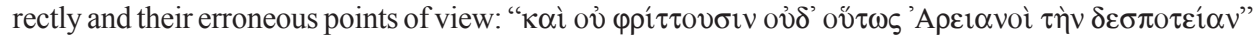
(cf. P. Maas - C.Y. Trypanis, Sancti Romani Melodi Cantica. Cantica genuina, Oxford 1963, 62).

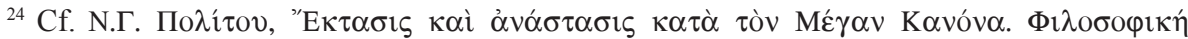




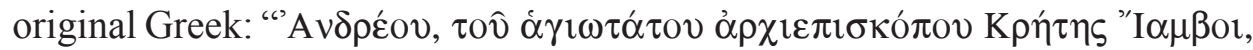

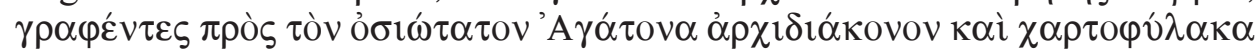

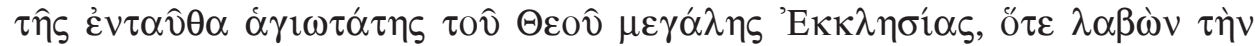

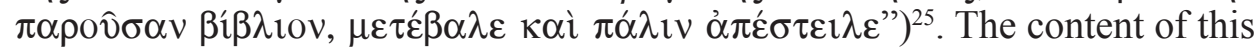
letter-confession, written shortly after the removal of Philippicus (ca 714), proves the Orthodox adherence of Andrew ${ }^{26}$, adherence expressed, moreover, in some personal homilies ${ }^{27}$.

Within thought and anti-heretical polemics could be evaluated nevertheless the troparion 10 of the first ode and the first troparion of the nine odes:

"As a potter molds his clay, Thou hast fashioned my flesh and my bones, giving me breath and life. Now accept me in repentance, $\mathrm{O}$ my Maker and Re-

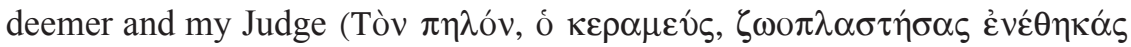

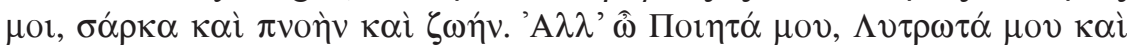

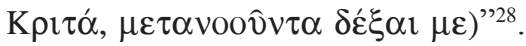

"My mind is wounded, my body is feeble, my spirit is sick, my speech has lost its power, my life is ebbing, and the end is at the door. What shalt thou do, O miserable soul, when the Judge comes to examine thy deeds? ('O vov̂s

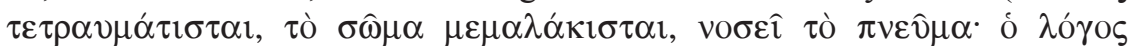

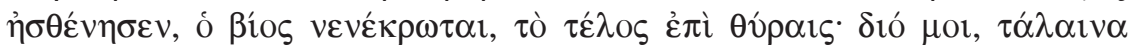

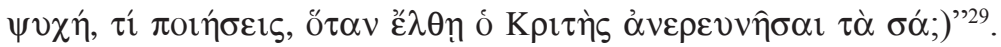

We may wonder: why the Byzantine poet prefers a chain of four elements (two for each human component)? ${ }^{30}$ Could we talk here about any polemic intention against Apollinarism and Trichotomist thought, initially promoted by Origen? As Nikolaos G. Politis ${ }^{31}$ emphasizes, in this reference of Andrew, who synthesizes the thinking of Church against Trichotomist, the theme of man's salvation is emphasized?: "As is accepted, Christ became man and deified the

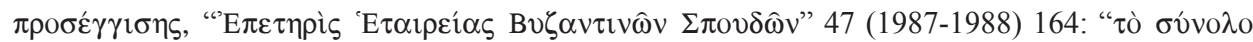

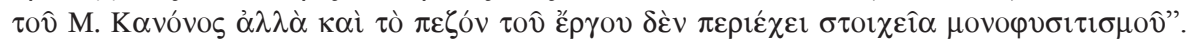

${ }^{25}$ Andreas Cretensis, Magnus Canon, PG 97, 1437C - 1444B. For the critical edition and a short introduction about this letter-confession, see: A. Heisenberg, Ein jambisches Gedicht des Andreas von Kreta, ByZ 10 (1901) 505-514.

${ }^{26}$ Cf. Heisenberg, Ein jambisches Gedicht des Andreas von Kreta, p. 511 (110-111. 113-118):

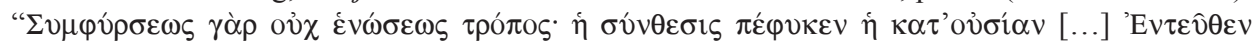

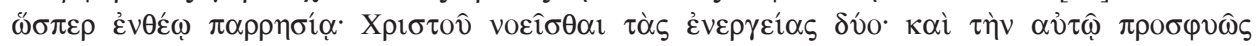

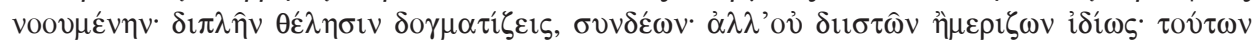

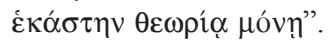

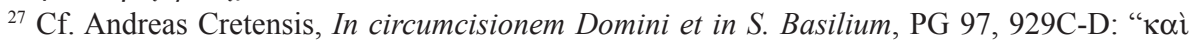

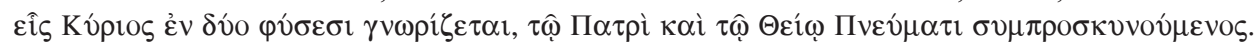

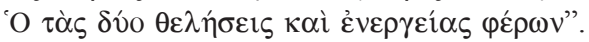

${ }^{28}$ Idem, Magnus Canon, PG 97, 1332C.

${ }^{29}$ Ibidem, PG 97, 1380D.

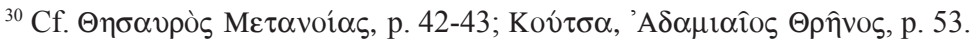

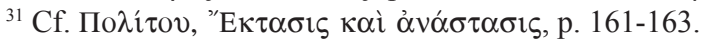


human nature. If in the human the mind it's brought from outside, then the salvation of man is not complete" ${ }^{32}$. Also, the terminology related to cikw v word has no reference to the Iconoclastic movement, which was unleashed in the year 726 by Byzantine Emperor Leo III the Isaurian ${ }^{33}$. All Andrew's

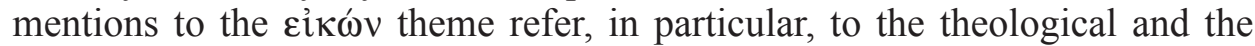
anthropological content of them and certainly not to the crisis of destroying icons, that Andrew wasn't unfamiliar with in his period ${ }^{34}$. In many stanzas Andrew laments the dark situation in which the sin has brought the man, but we should not understand, that, through these texts, the author aims to combat the iconoclastic crisis and to support the icons: "I have defiled that which was made in Thine image and likeness, O, Savior" 35 " "I have adorned the idol of my flesh with the diverse clothing of my shameful thoughts" ${ }^{\prime 36}$.

3. The Mariological problem. Regarding the Mariological problem we should consider here two major terminological aspects: one related to the use of the Nestorian term $\theta \varepsilon \varepsilon_{0} \delta \chi^{\alpha} \varsigma^{37}$ and the second related by using of Cyrillian

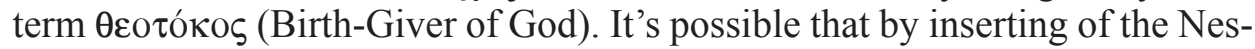
torian term $\theta \varepsilon o \delta$ ó $\chi 0 \varsigma$ - in facto, met only once in the text of Great Canon ${ }^{38}$ - Andrew fights against Nestorianism itself? We do not think so! The argument is based on the historical fact that the Nestorian concept with a double

${ }^{32}$ Ibidem 162.

${ }^{33}$ The problem of rejection of the Holy icons causes to Ioannes Fountoulis to declare that, in

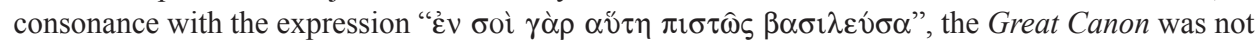
written in the city of Constantinople and, therefore, not even in the Leon's III period. His assumption would be based on the interrogation: how is possible for Andrew to mention a Christian emperor

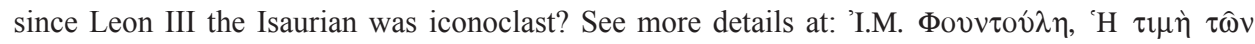

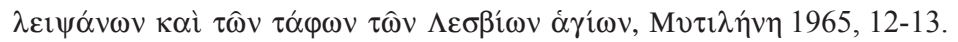

${ }^{34}$ How Andrew sees the Iconoclastic crisis from his period, see in his own short homily De SS. Imaginum Veneratione (PG 97, 1302D - 1304D), where the authour gives three historical examples ( $\delta \pi \delta \delta \varepsilon \imath \gamma \mu \alpha$ ) about the presence of icons in the Church's life. For more informations about this subject, see: A. Kazhdan, A History of Byzantine literature (650-850) (in collaboration with L.F. Sherry - Ch. Angelidi), The National Hellenic Research Foundation, Institute for Byzantine Research, Athens 1999, 39-40.

${ }^{35}$ Andreas Cretensis, Magnus Canon, PG 97, 1337B.

${ }^{36}$ Ibidem, PG 97, 1337B.

${ }^{37}$ See F. Loofs, Nestoriana. Die Fragmente des Nestorius, Hale 1905, 263, v. 11-13: "For-

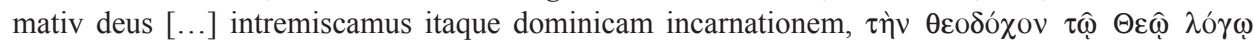
$\sigma v v \theta \varepsilon \circ \lambda \sigma \gamma \hat{\omega} \mu \varepsilon v \mu \rho \rho \varphi \eta ́ v "$ and 276, v. 1-6: "dominicae itaque humanitatis susceptionem cola-

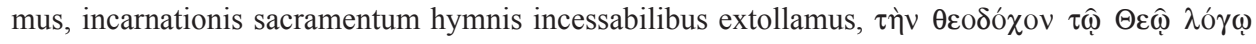

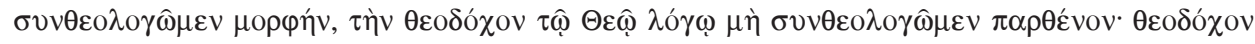

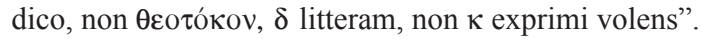

${ }^{38}$ Cf. Andreas Cretensis, Magnus Canon, PG 97, 1341D. 
meaning ${ }^{39}$, against which Basil of Seleucia ${ }^{40}$ and Proclus of Constantinople ${ }^{41}$ showed so much adversity, has become accepted from the sixth century by the Orthodox thinking. We cannot forget here, moreover, the significant contribution of Romanos the Melodist, used in his (supposed) Akathist Hymn, when he proclaims the doctrinal truth that "having received Virgin to God in her womb

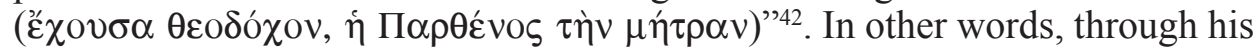
using, Andrew wants to emphasize not only the reality of "filling" of the Nestorian term with Orthodox connotation, but even the Ecumenical reality of the two Theological traditions (Antioch and Alexandrian) who meet in a perfect symphony in the Byzantine hymnography. The reality that Andrew of Crete, after four centuries, uses this term doesn't imply directly that he is aiming at the polemical intensions. We believe that it remains anchored in the Church's Tradition, which sees in the Virgin Mary "the womb" who contained Him Who

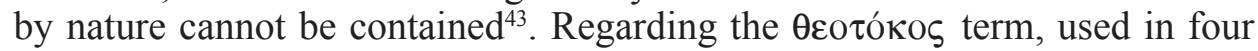
contexts ${ }^{44}$, Andrew develops the hermeneutical meaning of the Church and therefore the Cyrillian Theology imposed in the early of the fourth century:

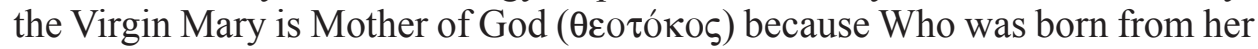

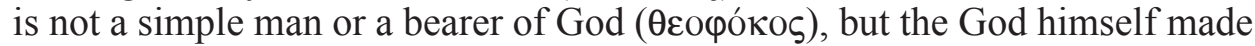
$\operatorname{man}^{45}$. In the womb of the Mother of God flesh was made and the Son of God himself was born, according to His human nature ${ }^{46}$; for this reason the Church glorifies the Mother of God which "has given birth to Christ God, One of the

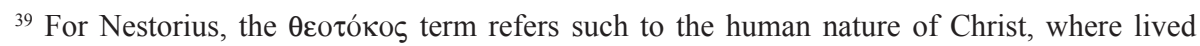

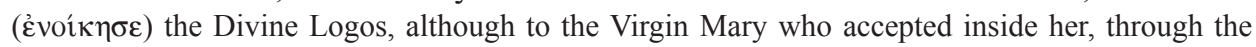

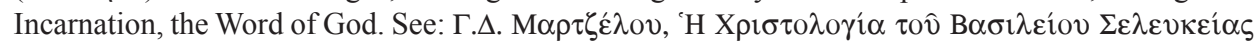

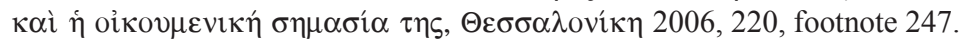

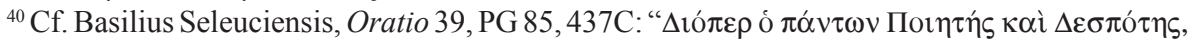

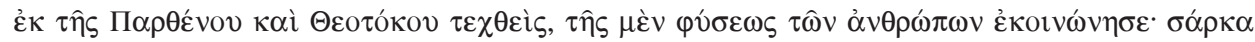

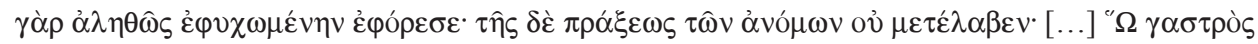

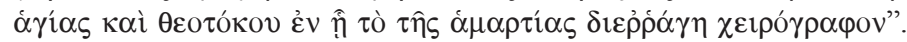

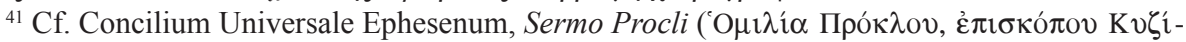

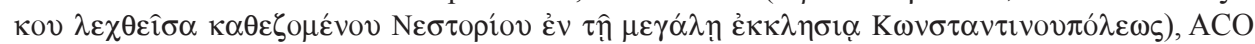

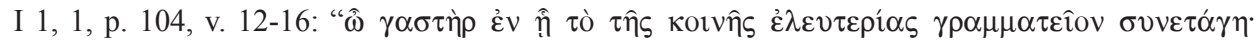

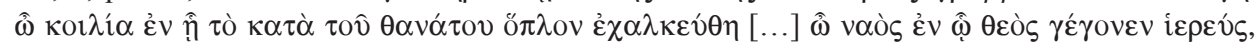

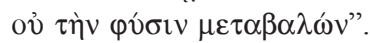

${ }^{42}$ A.C. Trypanis, Fourtheen Early Byzantine Cantica, vol. 5, Wien 1968, 31.

${ }^{43}$ Cf. Andreas Cretensis, Magnus Canon, PG 97, 1373C.

${ }^{44}$ Cf. ibidem, PG 97, 1336B, 1340A, 1361A, 1377D. Apart from these four uses, Andrew uses

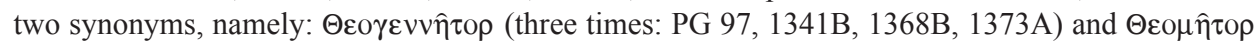
(once: PG 97, 1345B).

${ }^{45}$ Cf. Cyrillus Alexandrinus, Epistula 17: Cyrilli ad Nestorium de Excomunicatione, PG 77,

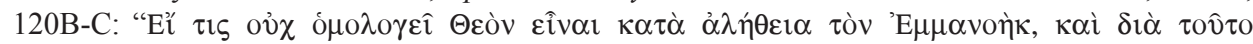

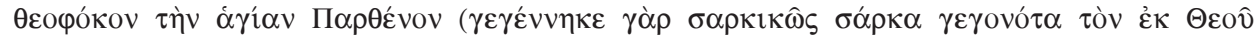

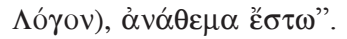

${ }^{46}$ Cf. Andreas Cretensis, Magnus Canon, PG 97, 1377D. 
undivided Trinity, and has opened the Heavens to us on earth"47. In the thinking of Andrew the person who rejects the attribute of Virgin Mary of being $\theta \varepsilon 0 \tau$ óкos, rejects even the Incarnation of the Son of God and the reality that He became for us a real man, wearing all of us, apart from our sin: "Christ became man by assuming my flesh and He willingly experienced all that belongs to our nature apart from our $\sin ^{\prime 4}$.

But this poetic record of dogmatic truth does not imply that the Byzantine Hymnographer aims at polemical intentions, given the reality that, in his period, the Cyrillian term did not raise any problem with his acceptance.

$$
* * *
$$

We must point from the beginning that in the entire Canon does not exist any direct mention about various heresies or polemical implications. We believe that this reality exists because of the simple reason that the Byzantine Hymnographer didn't intended to compose a work, which would argue and develop the anti-heretical fight of the Church, although in that period the Monothelitism problem still born controversy. Contrariwise the Great Canon is a prayer-text illustrating and dramatizing the way of turning toward one's self in a dialectical and typological relationship with biblical narratives ${ }^{49}$. Perhaps the deficiency of such polemical intentions and passing over of heresies (regardless of their nuance) could be explained through the desire of the author to provide a prayer for worship, in which the ecclesiastical congregation was invited to the meditation and the deep search of the creature's Creator.

\section{(Summary)}

It is known that the fundamental work of Andrew of Crete, probably written in the early of the eighth century, is penitential one, indicating continuing human need for repentance. Beyond a systematic exposition of Holy Scripture and its models (negative and positive), the Great Canon calls for deep meditation about life and its transience. Even the Byzantine author herself testifies this fact, saying: "Where shall I begin to lament the deeds of my wretched life? How shall I begin, O Christ, to relieve my present tears? But as Thou art deeply compassionate, grant me forgiveness of sins" (Ode 1, 1). But can we speak in the text of the Great Canon about polemical intentions against heresies? Can we find passages to develop the theological opinion against various heresies arisen within the Church over the eight centuries? If so, which ones and what heresy combat? This essay is at stake we want to present it.

\footnotetext{
${ }^{47}$ Ibidem, PG 97, 1373A-B.

${ }^{48}$ Ibidem, PG 97, 1381A.

${ }^{49}$ Cf. Krueger, The Great Kanon of Andrew of Crete, p. 63.
} 


\section{CZY „WIELKI KANON” ANDRZEJA Z KRETY \\ MÓWI O HEREZJACH I ICH ZWALCZANIU? \\ KILKA KRÓTKICH UWAG}

\section{(Streszczenie)}

Powszechnie jest wiadome, że fundamentalne dzieło Andrzeja z Krety, napisane prawdopodobnie na początku VIII wieku, jest penitencjałem wskazującym na nieustającą potrzebę ludzką do skruchy. Oprócz systematycznego wykładu Pisma Świętego i typów tego wyjaśniania (negatywny i pozytywny), Wielki Kanon wzywa też do głębokiej medytacji na temat życia i jego krótkotrwałości. Nawet sam autor bizantyński świadczy o tym fakcie, mówiąc: „Od czego zacząć mam opłakiwanie czynów nędznego życia mego? Jakiż początek skargi żałosnej dzisiaj uczynię, o Chryste? O miłosierny, udziel win moich odpuszczenia!” (Oda 1, 2). Czy możemy jednak mówić o obecności w tekście Wielkiego Kanonu polemicznych akcentów przeciw herezjom? Czy możemy znaleźć fragmenty przedstawiające poglądy teologiczne sprzeciwiające się różnym herezjom powstałym w Kościele w ciągu ośmiu wieków? Jeśli tak, to które z nich i jakie herezje zwalczają? Niniejsze opracowanie próbuje przedstawić to zagadnienie.

Key words: Andrew of Crete, hymnography, hymnographer, heresy, heretics,

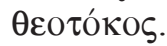

Słowa klucze: Andrzej z Krety, hymnografia, hymnograf, herezja, heretycy,

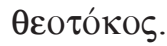

\section{BIBLIOGRAPHY}

\section{Sources}

Andreas CRetensis, De Sanctarum Imaginum Veneratione homilia, PG 97, 1301-1304.

Andreas Cretensis, Homilia de exaltatione s. crucis, ed. M. de Groote: Andrew of Crete's

Homilia de exaltatione s. crucis (CPG 8199; BHG 434f.). Editio princeps, HTR 100 (2007) 443-487.

Andreas Cretensis, Magnus Canon, PG 97, 1329-1386.

Andreas Cretensis, In circumcisionem Domini et in S. Basilium oratio, PG 97, 913-932.

Basilius Seleuciensis, Orationes, PG 85, 27-461.

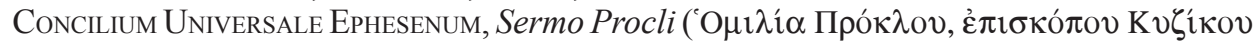

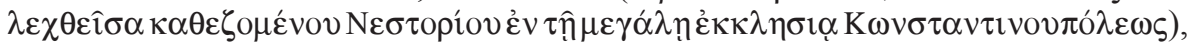
ACO I 1, 1, ed. E. Schwartz, Berolini - Lipsiae 1928, 103-107.

Cyrillus Alexandrinus, Epistula 17: Cyrilli ad Nestorium de Excomunicatione, PG 77, 105-121.

Theophanes, Chronographia, PG 108, 63-1009.

\section{Literature}

CLément O., Le chant des larmes. Essai sur le repéntir. Suivi de la traduction du poème sur le repentir par saint André de Crète, Paris 1982. 
Cunnigham M.B., Andreas of Crete's Homilies on Lazarus and Palm Sunday: a Critical Edition and Commentary, Birmingham 1983.

Cunningham M.B., Andreas of Crete's homilies on Lazarus and Palm Sunday: the Preacher and his Audience, StPatr 31 (1997) 22-41.

Cunningham M.B., Andrew of Crete: A High-Style Preacher of the Eighth Century, in: Preacher and His Audience: Studies in Early Christian and Byzantine Homiletics, ed. M.B. Cunnigham - P. Allen, Leiden - Boston - Köln 1998, 267-293.

ÉMEREAU C., Hymnographi Byzantini quorum nomina in litteras digessit notulisque adornavit, EO 21 (1922) 258-279.

Follieri E., Un canone inedito di S. Andrea di Creta per l'Annunciazione (Vat. gr. 2000 e Crypt. 4. $\alpha$. VII), in: Collectanea Vaticana in honorem Anselmi M. Card. Albareda, Studi e Testi 219, Città del Vaticano 1962, 337-357.

Heisenberg A., Ein jambisches Gedicht des Andreas von Kreta, ByZ 10 (1901) 505-514.

KazHDAN A., A History of Byzantine literature (650-850) (in collaboration with L.F. Sherry - Ch. Angelidi), The National Hellenic Research Foundation, Institute for Byzantine Research, Athens 1999.

Krueger D., The Great Kanon of Andrew of Crete, the Penitential Bible, and the Liturgical Formation of the Self in the Byzantine Dark Age, in: Between Personal and Institutional Religion. Self, Doctrine, and Practice in Late Antique Eastern Christianity, ed. B. Bitton-Ashkelony - L. Perrone, Turnhout 2013, 57-97.

Loofs F., Nestoriana. Die Fragmente des Nestorius, Hale 1905.

MaAs P. - Trypanis C.Y., Sancti Romani Melodi Cantica. Cantica genuina, Oxford 1963.

Magri M.A., L'inedito Canon de Requie di Andrea Cretese, "Helikon" 9-10 (1969-1970) 475-513.

Mercati S.G., Nota a due passi del canone di Sant'Andrea per San Giorgio, "Byzantion" 32 (1962) 311-312.

Prelipcean A., From Adam to Moses: the Typology of the Old Testament characters from the Kontakia of Romanos the Melodist and its Assessment on the Great Canon of Andrew of Crete", "Review of Ecumenical Studies" 7 (2015) 388-421.

Schiró G., Caracteristiche dei canoni di Andrea Cretese. Studio su alcune composizioni

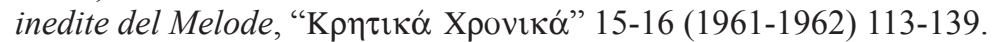

Trypanis A.C., Fourtheen Early Byzantine Cantica, vol. 5, Wien 1968.

Vailhé S., Saint André de Crète, EO 5 (1901-1902) 378-387.

Vinogradov A., Viața Sfântului Andrei Criteanul, Arhiepiscopul şi Mitropolit al Cretei (Schiță aghiografică), "Luminătorul” 72 (1932) 114-120 (part 1), 147-153 (part 2).

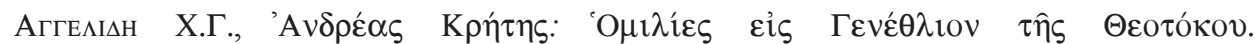

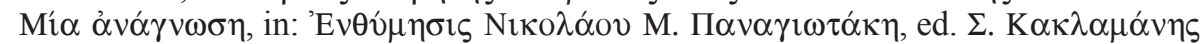

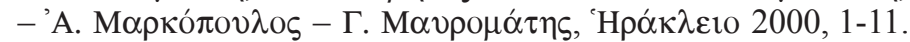

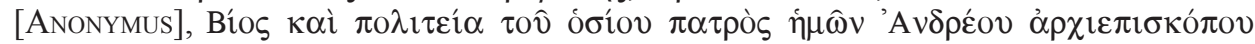

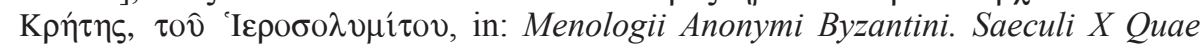
Supersunt, ed. V.V. Latyšev, Subsidia Byzantina XII, vol. 2, Leipzig 1970², 136-137;

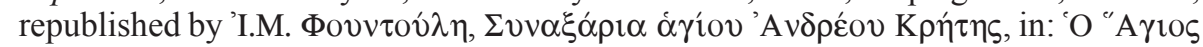

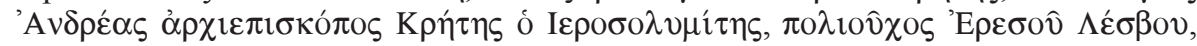

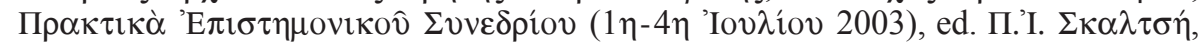

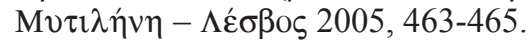

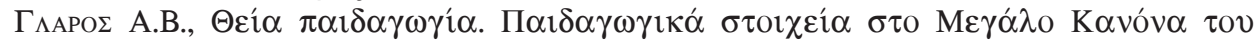

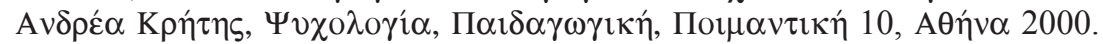




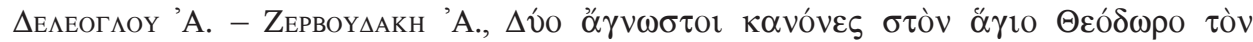

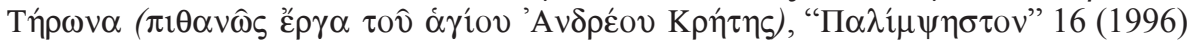
113-148.

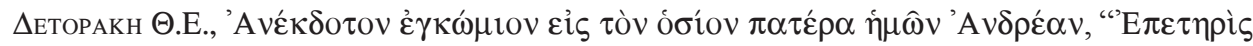

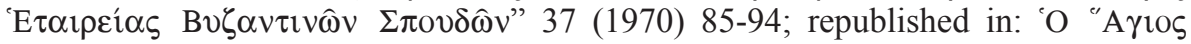

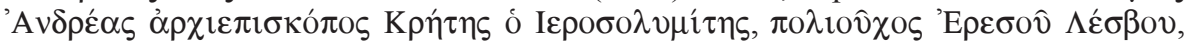

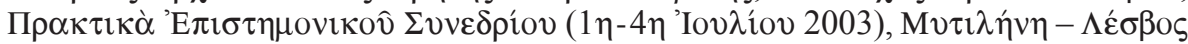
2005, 403-415.

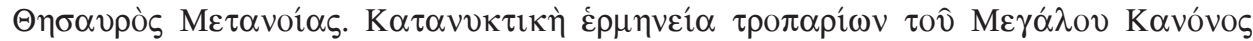

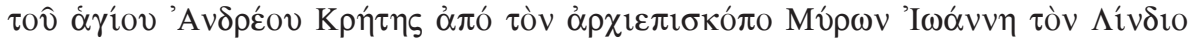

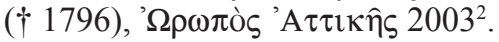

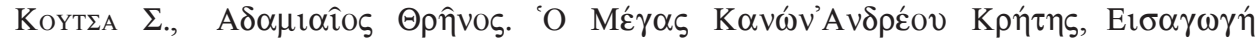

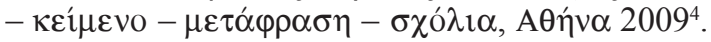

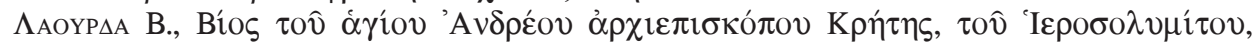

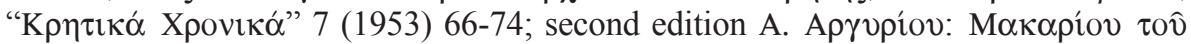

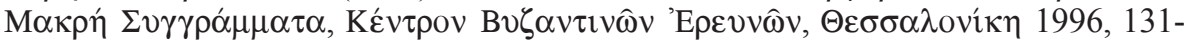

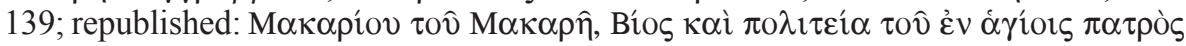

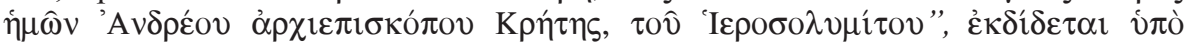

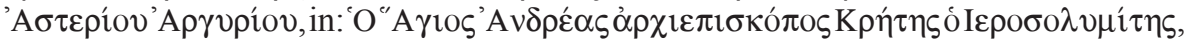

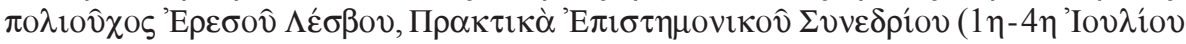

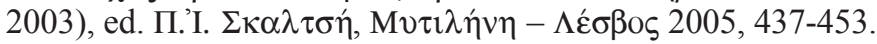

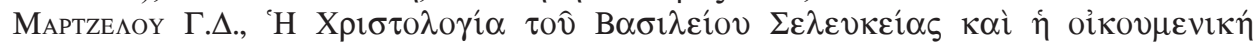

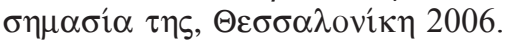

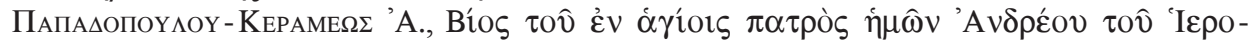

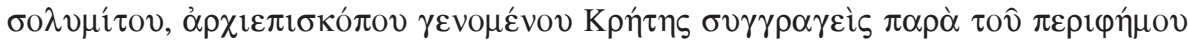

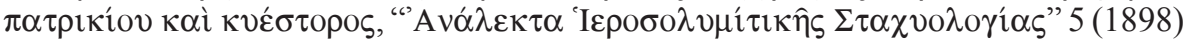

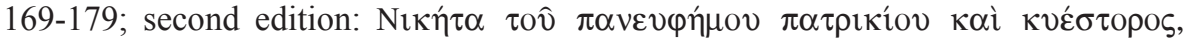

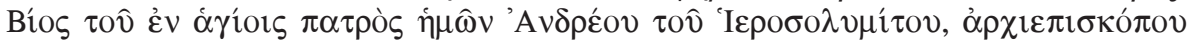

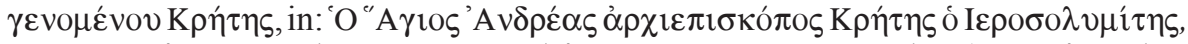

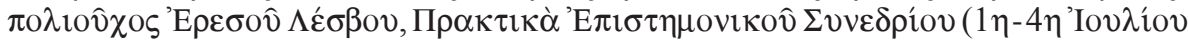

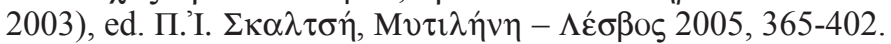

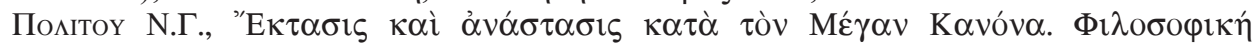

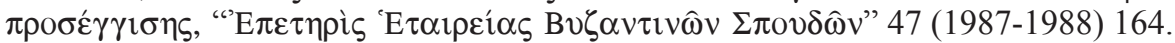

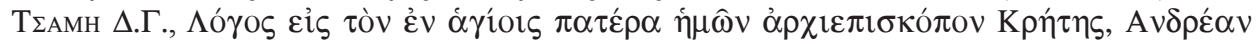

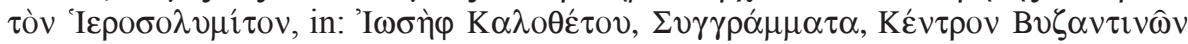

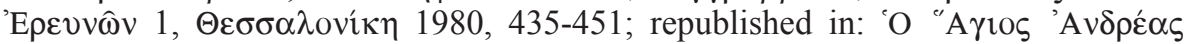

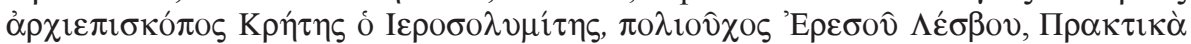

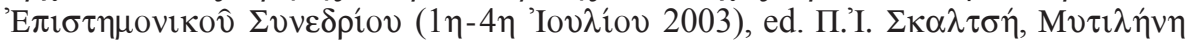

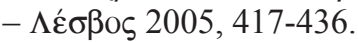

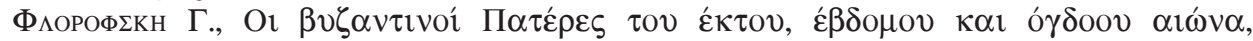

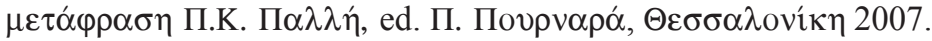

ФочNточ

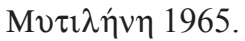

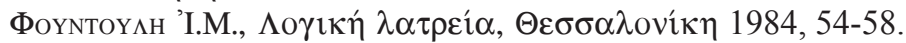


